\title{
Automatic submerged arc welding
}

\author{
Smirnova, Z.V. ${ }^{1}$, Kutepova L.I. ${ }^{2}$, Vaganova O.I. ${ }^{3}$, Cherney O.T. ${ }^{4}$, Romanovskaya E.V. ${ }^{5}$ \\ ${ }^{1}$ Minin Nizhny Novgorod State Pedagogical University (Minin University), Nizhny Novgorod, Russian Federation, \\ z.v.smirnova@mininuniver.ru \\ ${ }^{2}$ Minin Nizhny Novgorod State Pedagogical University (Minin University), Nizhny Novgorod, Russian Federation, \\ lubovkutepova@mail.ru \\ ${ }^{3}$ Minin Nizhny Novgorod State Pedagogical University (Minin University), Nizhny Novgorod, Russian Federation, \\ vaganova_o@mail.ru \\ ${ }^{4}$ Minin Nizhny Novgorod State Pedagogical University (Minin University), Nizhny Novgorod, Russian Federation, \\ fiolet1975@mail.ru \\ ${ }^{5}$ Minin Nizhny Novgorod State Pedagogical University (Minin University), Nizhny Novgorod, Russian Federation, \\ romanovskaya_ev@mininuniver.ru
}

\begin{abstract}
The article reveals the technology of automatic submerged arc welding. The purpose of some grades of fluxes and wires. An example of a circuit for automatic submerged arc welding is given. The technical characteristics of the surfacing wire with the help of which the restoration of machine parts takes place are given.
\end{abstract}

Key words: Submerged arc welding, technological process, welding arc.

\section{INTRODUCTION}

The welding process is understood as a technological process, as a result of which non-permanent compounds are obtained which use interatomic atoms and intermolecular bonds in the surfaces of the manufactured product.

Welding technologies have advantages over other compounds; on the basis of this, such a connection is widely used in various industries and provides a leading place as a metal processing process.

There are several welding methods that are divided into pressure welding (cold, friction, ultrasound, explosion, contact, gas press) and melting (electric arc, plasma, electroslag, gas, laser, electron beam, etc.) [1].

If the surfaces of two connected products are thoroughly cleaned and assembled under high pressure so that an interaction occurs between the ionized atoms, a strong weld will be obtained. This is the essence of cold welding of ductile metals.

To date, industrial development is widely used automatic flux welding, especially electric arc welding, which is widely used in the restoration of parts.

\section{RESEARCH}

The process of submerged arc welding, Figure 1, determines the burning of the arc between the welding wire 1 and the surface of the product 5 under the layer of granular flux 4. Special rollers 2 feed the electrode wire into zone 6 of the arc.

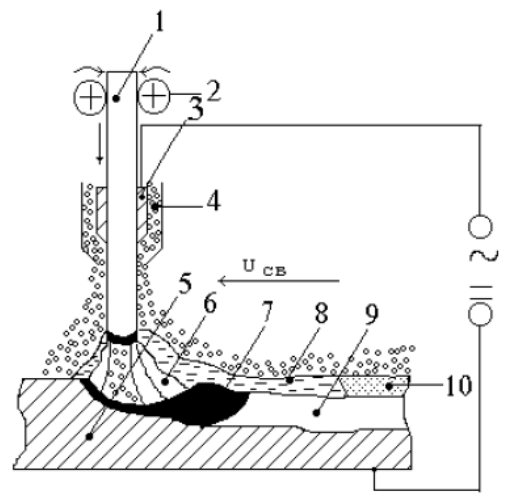

Figure 1: Scheme of automatic submerged arc welding

Welding current (alternating or constant direct or reverse polarity) is supplied to the wire using a sliding contact 3 , and to the product - a constant contact. The welding arc burns in a gas bubble, which is formed as a result of melting of flux and metal.

In addition, the molten metal is protected from the environment by a layer of molten flux 8 . As the arc moves away from the welding zone, the molten flux solidifies and forms a slag crust 10 , which subsequently easily separates from the surface of the weld.[2].

The flux is filled in front of the arc from the hopper with a layer 40-80 mm thick and 40-100 mm wide. Unmelted flux after welding is reused. The molten electrode and base metals 7 in the weld pool are mixed and upon crystallization form a weld 9 .

Welding with wire (wire electrode) is predominantly used. However, in recent years, surfacing with tape or combined electrodes is becoming more common.

The advantages of submerged arc welding include: high productivity of the process, due to the use of high currents, deep penetration, an almost complete absence of metal loss due to fumes and spatter (no more than 3\%); high quality of the deposited surface as a result of good flux protection of the weld pool; a small amount of nonmetallic inclusions in the weld metal; the possibility of alloying deposited metal through a flux; better use of arc heat (compared to manual welding, energy consumption is 
reduced by $30-40 \%$ ); the best working conditions of the welder and a number of others [3].

- $\quad$ however, this type of welding has a number of disadvantages: significant heating of the product;

- $\quad$ increased fluidity of molten metal and flux, which allows welding only in the lower position and surfacing parts with a diameter of at least $40 \mathrm{~mm}$;

- $\quad$ the need for individual cases of repeated heat treatment;

- $\quad$ impossibility tdirect observation of the formation of the weld.

Submerged arc welding is used in the manufacture and repair of structures and critical parts that must be reliable when operating in low and high temperatures [6].

\section{RESULT AND DISCUSSION}

For the type of welding and surfacing under consideration in the repair of rolling stock, fluxes of the AN-348A, AN$348 \mathrm{~V}$, OSTs-45, ANTs-1 brands and others are most widely used [4]. Such fluxes are recommended for welding low- and medium-carbon steels. For welding and surfacing of low- and medium-alloy steels, fluxes AN348A, AN-60, AN-22 and others are used in combination with wires of the Sv-08A, Sv-08GA grades and wires alloyed with chromium, molybdenum, nickel.

Table 1 shows the purpose of some grades of fluxes and wires [6].

Table 1: Fluxes and wire for automatic welding

\begin{tabular}{|c|c|c|}
\hline $\begin{array}{l}\text { Flux } \\
\text { grade }\end{array}$ & Flux appointment & $\begin{array}{l}\text { Featured Brands } \\
\text { wire }\end{array}$ \\
\hline \multirow{15}{*}{$\begin{array}{l}\text { AH- } \\
348 \mathrm{~A}, \\
\text { AH- } \\
348 B, \\
\text { АНЦ-1 } \\
\text { AH-60 } \\
\text { AH-22 } \\
\text { AHK-30 }\end{array}$} & \multirow{15}{*}{$\begin{array}{l}\text { Welding and surfacing } \\
\text { of products wide } \\
\text { carbon and } \\
\text { nomenclature items } \\
\text { low alloy steels } \\
\text { Welding carbon and } \\
\text { low alloy } \\
\text { steel } \\
\text { Welding of low and } \\
\text { medium alloy steels } \\
\text { Welding carbon and } \\
\text { low alloy } \\
\text { steels, including cold- } \\
\text { resistant fine-grained } \\
\text { high strength }\end{array}$} & \multirow{11}{*}{$\begin{array}{l}\text { Св-08, Св-08А, } \\
\text { Св-08ГА, Св- } \\
10 Г 2 \\
\text { Св-08, Св- } \\
08 Г А ; ~ \\
\text { Св-08ХМ, } \\
\text { Св-10НМА } \\
\text { Св-08ГА, } \\
\text { Св-08ХМ, } \\
\text { Св-08ХМФ, } \\
\text { Св-08ХГНМГА }\end{array}$} \\
\hline & & \\
\hline & & \\
\hline & & \\
\hline & & \\
\hline & & \\
\hline & & \\
\hline & & \\
\hline & & \\
\hline & & \\
\hline & & \\
\hline & & Св-08, Св- \\
\hline & & 08ГА \\
\hline & & 08XM \\
\hline & & $\begin{array}{l}\text { Св-08ХМФ, } \\
\text { Св-08ХГНМТА }\end{array}$ \\
\hline
\end{tabular}

In order to obtain layers with enhanced physicomechanical properties during restoration when surfacing under flux, surfacing wires are used, which are divided into 3 groups: from carbon steel of the type Np-30, Np-40, Np-80 and others; from alloy steel Np-30Kh5, Np-30GSA, Np40KhFA and others; from high alloy steel, for example, Нп-4Х13, Нп-45Х4В3Ф, Нп-45Х2В8Т and others [5].

To increase the productivity of submerged-arc surfacing, solid or powder strips $0.3-1 \mathrm{~mm}$ thick and $20-100 \mathrm{~mm}$ wide are used as surfacing material.

\section{CONCLUSION}

Thus, table 2 shows the technical characteristics of some brands of surfacing wires recommended for the restoration of rolling stock parts.

Table 2: Surfacing wire specifications

\begin{tabular}{|c|c|c|c|}
\hline $\begin{array}{l}\text { Steel band } \\
\text { wire }\end{array}$ & $\begin{array}{l}\text { Brand } \\
\text { wire }\end{array}$ & $\begin{array}{l}\text { Hardness } \\
\text { deposited } \\
\text { metal }\end{array}$ & $\begin{array}{l}\text { Sample } \\
\text { Nomenclature } \\
\text { recoverable } \\
\text { of details }\end{array}$ \\
\hline Carbon & 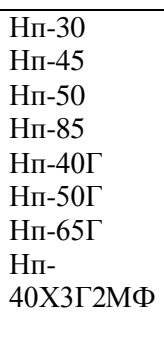 & $\begin{array}{l}\text { HB } 160-220 \\
\text { HB } 170-230 \\
\text { HB } 180-240 \\
\text { HB } 280-350 \\
\text { HB } 180-240 \\
\text { HB } 200-270 \\
\text { HB } 230-310\end{array}$ & $\begin{array}{l}\text { Axles, Shafts } \\
\text { Also } \\
\text { Support rollers } \\
\text { Crankshafts, } \\
\text { universal } \\
\text { joints }\end{array}$ \\
\hline Alloyed & $\begin{array}{l}\text { Нп- } \\
40 \mathrm{X} 2 \Gamma 2 \mathrm{M}\end{array}$ & HRC 40-44 & \\
\hline highly alloyed & $\begin{array}{l}\text { Нп-50ХФА } \\
\text { Нп-30Х13 } \\
\text { Нп- } \\
\text { Х20Н80Т }\end{array}$ & $\begin{array}{l}\text { HRC 56-57 } \\
\text { HRC 46-52 } \\
\text { HRC 40-47 } \\
\text { HB } 180-220\end{array}$ & $\begin{array}{l}\text { Crankshafts of } \\
\text { internal } \\
\text { engines } \\
\text { combustion } \\
\text { spline shafts } \\
\text { Crankshaft } \\
\text { journals, } \\
\text { plungers } \\
\text { Hydraulic } \\
\text { presses. } \\
\text { Engine } \\
\text { exhaust valves } \\
\text { internal } \\
\text { combustion }\end{array}$ \\
\hline
\end{tabular}

The creation of an automatic submerged arc welding is the largest achievement of modern welding equipment. The original idea of the submerged arc welding method belongs to the inventor of the arc welding method N. G. Slavyanov. He used crushed window glass as a flux.

The development of automatic submerged arc welding has changed the idea of the scope and possibilities of automating the arc welding process. In a number of industries, automatic welding has almost completely replaced manual welding.

\section{REFERENCES}

1. Bartels, N. A. Metallography and heat treatment of metals / N.A. Bartels. - M .: State Scientific and Technical Publishing House, 2018 .-- 376 c.

2. Smirnova Zh.V., Cherney O.T. Technology of construction materials study guide / University of Minin. Nizhny Novgorod, 2019.

3. Y. Pratapa Reddy, Dr. K. L Narayana, Dr. M. Kedar Mallik. Electro-chemical behavior of different metals in Sodium Chloride solution. // International Journal of Emerging Trends in Engineering Research, 7 (11), November 2019, 71 Volume 7, No. November 11, 2019.

4. EkoJulianto, WaluyoAdi Siswanto, Marwan Effendy Characteristics of Temperature changes and Stress of Float Glass under Heat Radiation // International 
Journal of Emerging Trends in Engineering Research, Volume 7, No. September 9, 2019.

https://doi.org/10.30534/ijeter/2019/03792019

5. Cherney, O.T., Zotova, V.A., Permovsky, A.A., Smirnova, Z.V., Vaganova, O.I. Hydrogenous phase concentration: Impact on the structural condition and fracture mechanics of technically pure titanium after different conditions of hydrogenation (2019) International Journal of Innovative Technology and Exploring Engineering 8(6), c. 535-539

6. Cherney, O.T., Smirnova Zhanna, V., Gruzdeva, M.L., Semakhin, E.A., Vaganova, O.I. The tendency of highstrength aluminum alloy 1933 to corrosion resistance 2020 International Journal of Emerging Trends in Engineering Research 8(6), c. 2293-2295

https://doi.org/10.30534/ijeter/2020/15862020 